\title{
Antiangiogenic Cancer Therapy with Microencapsulated Cells
}

\author{
PASQUALE CIRONE, ${ }^{1}$ JACQUELINE M. BOURGEOIS, ${ }^{2}$ and PATRICIA L. CHANG ${ }^{1,3}$
}

\begin{abstract}
Inhibition of angiogenesis has led to tumor suppression in several cancer models. Although administering purified recombinant antiangiogenic product is effective, alternative approaches through genetic manipulation may be more cost-effective. We propose to implant nonautologous recombinant cells secreting angiostatin for systemic delivery of angiostatin in cancer treatment. These cells are protected from graft rejection in alginate microcapsules to function as "micro-organs" to deliver angiostatin in vivo. This approach was tested by implanting encapsulated mouse myoblast $\mathrm{C} 2 \mathrm{C} 12$ cells genetically modified to secrete angiostatin into mice bearing solid tumor. Angiostatin was detected in sera of the treated mice. Efficacy was demonstrated by suppression of palpable tumor growth and improved survival. At autopsy, angiostatin localized to residual tumors and high levels of angiostatic activity were detected in tumor extracts. Tumor tissues showed increased apoptosis and necrosis compared with those from untreated or mock-treated mice. Immunohistochemical staining against von Willebrand factor, an endothelial cell marker, showed that within tumors from the treated mice, the neovasculature was poorly defined by endothelial cells, many of which were undergoing apoptosis. However, the tumors eventually developed neovasculature independent of endothelial cells. Such vascular mimicry would account for the lack of long-term efficacy despite persistent angiostatin delivery. In conclusion, implantation with nonautologous microencapsulated cells is feasible for systemic delivery of angiostatin, resulting in localization of angiostatin to tumors and targeted apoptosis of the endothelial cells. Clinical efficacy was demonstrated by suppression of tumor growth and extension of life span. Although the potential of this cell-based approach for angiostatin-mediated cancer therapy is confirmed, long-term efficacy must take into account the possible escape by some tumors from angiogenesis inhibition.
\end{abstract}

\section{OVERVIEW SUMMARY}

Inhibition of angiogenesis by angiostatin has been shown to be an effective treatment in several animal models of cancer. In this study, we examine a potentially cost-effective strategy of delivering angiostatin by implanting nonautologous, genetically engineered cells that were immunoisolated from the host by microencapsulation. The advantage of this approach is that, once a suitable recombinant cell line is created, it can be used to treat patients without causing irreversible genetic changes as in most gene-based therapies. We now show that biologically active angiostatin can be delivered systemically from encapsulated cells engineered to secrete angiostatin. In tumor-bearing mice, the delivered angiostatin was found to reside predominantly in tumors, concurrent with endothelial cell apoptosis within the tumor mass. Mice bearing solid B16/F0/neu melanoma tumors re- ceiving this treatment showed tumor growth suppression and improved survival. Therefore, the implantation of immunoisolated, nonautologous cells capable of delivering angiostatin is a viable means of treating melanoma and potentially other cancers.

\section{INTRODUCTION}

$\mathbf{M}$ ICROENCAPSULATION is an alternative approach to somatic gene therapy in which a therapeutic protein is delivered by encapsulated recombinant cells (Chang et al., 1999). The microcapsules are designed to be permeable to the recombinant products and nutrients, but not to the host's immune mediators because of their larger size (Chang, 1995; Prakash and Chang, 1996; Rinsch et al., 1997; Cirone et al., 2001). This form of gene therapy has been applied successfully to treat several

${ }^{1}$ Department of Biology, ${ }^{2}$ Department of Molecular Medicine and Pathology, and ${ }^{3}$ Department of Pediatrics, McMaster University, Hamilton, Ontario L8N 3Z5, Canada. 
mouse models of Mendelian inherited diseases including growth hormone deficiency in dwarfism (Al-Hendy et al., 1995), $\beta$-glucuronidase deficiency in the lysosomal storage disease mucopolysaccharidosis type VII (MPSVII) (Ross et al., 2000a,b), and factor IX deficiency in hemophilia B (Van Raamsdonk et al., 2002).

Applying this strategy to the treatment of non-Mendelian disorders such as cancer is highly dependent on the nature of the cancer and the type of molecules chosen for tumor suppression (see review by Cirone et al., 2001). Hence, delivery of a variety of effectors such as cytochrome $P-450$ enzymes, endostatin, and cytokines has been applied successfully for the treatment of various types of cancer (Kroger et al., 1999; Joki et al., 2001; Read et al., 2001). In theory, this approach is particularly advantageous for the treatment of cancer with cytokines as it provides a constitutive and continuous source of the antineoplastic recombinant protein, thus circumventing the problems of toxicity and limited half-lives. However, when a cytokine fusion protein of interleukin 2 (IL-2) was delivered via microencapsulation, the proinflammatory nature of IL-2 was sufficient to prohibit extended delivery in vivo, thus limiting the efficacy to only short-term suppression of tumor growth (Cirone et al., 2002). Hence, the inherent properties of this immune-isolated, nonautologous form of cancer therapy may be more suited to delivering other gene products that are better tolerated and nontoxic to the host. We postulate that antiangiogenic therapy suits the above-described criteria well and have sought to test the efficacy of such therapy based on the delivery of angiostatin.

The prominent role of angiogenesis has been well established in cancer progression and angiostatin is an important factor shown to inhibit neovascularization and growth of Lewis lung metastasis (O'Reilly et al., 1994). Subsequent studies have shown that its antiangiogenic activity stems from kringle domains 1-3 (Cao et al., 1996), which correspond to regions with tumor-suppressing activity (MacDonald et al., 1999). In vitro, angiostatin specifically reduces endothelial cell proliferation (Cao et al., 1996; Gately et al., 1996; Sim et al., 1997; Heidtmann et al., 1999; Morikawa et al., 2000), migration (Gately et al., 1997; Claesson-Welsh et al., 1998; Stack et al., 1999), as well as invasion and tube formation (Gately et al., 1996; Barendsz-Janson et al., 1998; Claesson-Welsh et al., 1998; Griscelli et al., 1998). In vivo, angiostatin inhibits spontaneous angiogenesis in chick chorioallantoic membrane model assays (Sim et al., 1997) as well as basic fibroblast growth factor (bFGF)-induced corneal angiogenesis (Gately et al., 1996, 1997; Morikawa et al., 2000). Recombinant angiostatin also inhibits primary tumor growth as well as angiogenesis-dependent growth of metastases in mice (O'Reilly et al., 1996; Gately et al., 1997; Lannutti et al., 1997; Sim et al., 1997; Wu et al., 1997; Cao et al., 1998; Kirsch et al., 1998; Griscelli et al., 2000; Sacco et al., 2000).

In the present study, a $\mathrm{C} 3 \mathrm{H}$-derived mouse myoblast cell line, $\mathrm{C} 2 \mathrm{C} 12$, was engineered to continuously secrete angiostatin and was encapsulated into alginate-poly-L-lysine-alginate (APA) beads. The resulting microcapsules were implanted into the peritoneal cavities of nonautologous C57BL/6 mice bearing solid B16-F0/neu melanoma tumors to investigate the ability of this system to suppress tumor growth.

\section{MATERIALS AND METHODS}

\section{Cell lines}

Mammalian expression plasmid pRC-CMV-AST (kindly provided by Y. Cao; Cao et al., 1998) encodes mouse kringle regions $1-4$ of plasminogen with a hemagglutinin tag (HA) driven by a cytomegalovirus (CMV) promoter. A mouse myoblast cell line derived from $\mathrm{C} 3 \mathrm{H}$ mice, $\mathrm{C} 2 \mathrm{C} 12$ (CRL-1772; American Type Culture Collection [ATCC], Manassas, VA), was transfected with this plasmid using ExGen 500 according to the manufacturer's guidelines (Fermentas, Burlington, ON, Canada). Clones were screened for secretion of HA-tagged angiostatin by endothelial cell viability assay and confirmed with Western blot.

B16/F0/neu mouse cells used to generate tumors were as described previously (Cirone et al., 2002). A minimal tumor dose of $5 \times 10^{6}$ cells per animal has been established by a minimal tumor dose experiment (data not shown).

\section{Endothelial cell viability assay}

Angiogenic activity was quantified by endothelial cell growth as described previously (O'Reilly et al., 1994; Cao et al., 1996, 1998; Wu et al., 1997; Griscelli et al., 1998; Lucas et al., 1998; MacDonald et al., 1999; Moser et al., 1999). Briefly, $3 \times 10^{5}$ human umbilical vein endothelial cells (HUVECs) were plated into a 24-well plate in culture medium (M199 medium supplemented with $20 \%$ fetal bovine serum [FBS], $1 \%$ penicillin-streptomycin $[\mathrm{P} / \mathrm{S}]$, and endothelial cell growth factor supplement [400 mg/ml]) (Sigma, Mississauga, ON, Canada) and incubated for 3 days with either medium from angiostatin-secreting cells, or serum, or tissue extract homogenized in homogenization buffer (25 mM Tris, 0.1 M NaCl, 0.2\% Triton X-100, $\mathrm{pH} 7.6$ ) at $1 \mathrm{ml}$ of buffer per $100 \mathrm{mg}$ of wet weight tissue. Viability of the HUVECs was determined by alamarBlue assay (AccuMed International, Microbiology Division, Westlake, $\mathrm{OH}$ ) as per the supplier's instructions after the incubation. Rabbit angiostatin, a generous gift from M. Hatton (McMaster University, Hamilton, ON, Canada), was used as a standard.

\section{Animals}

Five- to 6-week old C57BL/6 (Charles River Laboratories, Wilmington, MA) female mice were used in accordance with Canadian Council on Animal Care guidelines. Serum from orbital bleeds or cardiac punctures was stored at $-70^{\circ} \mathrm{C}$ until use.

The tumor model was developed by injecting $5 \times 10^{6}$ B16/neu cells into the left flank of mice. Tumor dimensions were measured with calipers to estimate the volume according to $V=a b^{2} / 2$, where $a$ is the longest diameter and $b$ is the shortest diameter (Heike et al., 1997). Mice were killed with $\mathrm{CO}_{2}$ once the tumor volume reached $1 \mathrm{~cm}^{3}$ as per institutional guidelines for end-point criterion.

\section{Microencapsulation}

Alginate-poly-L-lysine-alginate (APA) microcapsules containing either parental $\mathrm{C} 2 \mathrm{C} 12$ cells or the derivative $\mathrm{C} 2 \mathrm{C} 12$-angiostatin-expressing cells (C2C12-AST) were constructed as previously described (Peirone et al., 1998; Van Raamsdonk and Chang, 2001). Briefly, cells were resuspended in filtered $1.5 \%$ 
alginate (improved Kelmar, a gift from NutraSweet Kelco, San Diego, CA) at a concentration of 2 million cells $/ \mathrm{ml}$ alginate solution, followed by a series of washes whereby coatings of polyL-lysine and alginate were added. The resulting APA-microencapsulated cells were used immediately for implantation. Capsules were visually inspected to confirm their integrity and uniform diameters of $\sim 400 \mathrm{~nm}$.

\section{Western blot analysis}

Western blots were performed according to standard procedures (Sambrook et al., 1989). Tissue extracts were prepared by brief sonication in homogenization buffer (as described above). Equal amounts of proteins in all samples, as determined by Bradford assay (Bio-Rad, Mississauga, ON, Canada), were loaded and confirmed by Ponceau S staining (Sigma) of the nitrocellulose membrane after electrophoresis and protein transfer. For the detection of angiostatin, a mouse anti-HA monoclonal primary antibody (Sigma) and an alkaline phosphatase-conjugated rabbit anti-mouse IgG $(\mathrm{H}+\mathrm{L})$ secondary antibody (Promega, Madison, WI) were used according to the manufacturer instructions, and visualized with standard 5-bromo-4-chloro-3-indolyl phosphate (BCIP)-nitro-blue tetrazolium (NBT) substrates (GIBCOBRL/Invitrogen Life Technologies, Carlsbad, CA).

\section{Histological analysis}

Tissues were fixed and processed for paraffin sectioning and hematoxylin and eosin (H\&E) staining by standard protocols (Histology Laboratory, McMaster University Hospital, Hamilton, ON, Canada). Mitotic and apoptotic indices were obtained by counting the corresponding cells in 10 high-power fields (HPFs; magnification, $\times 400$ ) per given slide (or over the entire area of the section in the case of smaller tumors). This was repeated for five slides per animal (five mice per group). When the tissue area was less than 10 HPFs, the entire area was included. These indices were expressed as percent mitotic cells per total viable cells (per HPF) and apoptotic nuclei per total number or cells (per HPF). Necrotic index was determined by the percent necrosis over the entire tumor area.

\section{Anti-von Willebrand factor immunohistochemistry}

After paraffin-embedded sections were deparaffinized, antigen retrieval was performed by proteinase $\mathrm{K}$ treatment for 5 min followed by blocking of the endogenous peroxidase activity by a 5-min treatment with $3 \% \mathrm{H}_{2} \mathrm{O}_{2}$ (pharmacy grade). Primary antibody (rabbit anti-human von Willebrand factor [vWF]; Dako, Mississauga, ON, Canada) was added at a 1:500 dilution (diluted in $0.1 \mathrm{M}$ phosphate buffer supplemented with $5 \%$ goat serum as a block) followed by a secondary antibody (EnVision+, goat anti-rabbit IgG conjugated to peroxidase; Dako) and stained with liquid 3,3'-diaminobenzidine (DAB) substrate-chromogen system (Dako) followed by counterstaining with hematoxylin.

The degree of vascularization was assessed by comparing the area of vascularization with the area of the tumor. Areas were digitally quantified by image capture of the entire tumor section with Image-Pro 6.0 software (Media Cybernetics, Silver Spring, MD). Viable and nuclear condensed (apoptotic) endothelialcells were counted per sectional area of tumor. Apoptosis measurements were validated with the TumorTACS in situ apoptosis detection kit (R\&D Systems, Minneapolis, MN). Values were reported as number of cells per sectional area of tumor.

\section{RESULTS}

Mouse C2C12 myoblasts were transfected with the plasmid pRC-CMV-AST encoding angiostatin cDNA fused to an HA tag (Cao et al., 1998). Forty clones (total screened, 48) positive for antiangiogenic activity against cultured HUVECs were examined by Western blot against the HA tag of the transgene product (Fig. 1). A positive band was found only in pRC-CMVAST-transfected cells (C2C12-AST) running at approximately $55 \mathrm{kDa}$ as expected of the angiostatin fusion protein.

Cells from the clone expressing the highest level of antiangiogenic activity were microencapsulated into alginate-poly-Llysine-alginate microcapsules. To determine whether angiostatin expression levels from these encapsulated cells may change after implantation, we implanted encapsulated $\mathrm{C} 2 \mathrm{C} 12$-angiostatin cells into the peritoneal cavities of normal C57BL/6 mice. Mice were killed each week and microcapsules were retrieved and analyzed for viability and transgene expression. On microcapsule retrieval, no gross anatomical signs of fibrosis or acute inflammatory responses were observed around the implanted encapsulated C2C12-angiostatin cells. Determination of cell number by alamarBlue reagent had shown an increasing number of viable cells throughout the 3-week experiment (Table 1) for microcapsules kept in vitro and those implanted intraperitoneally. Preim-

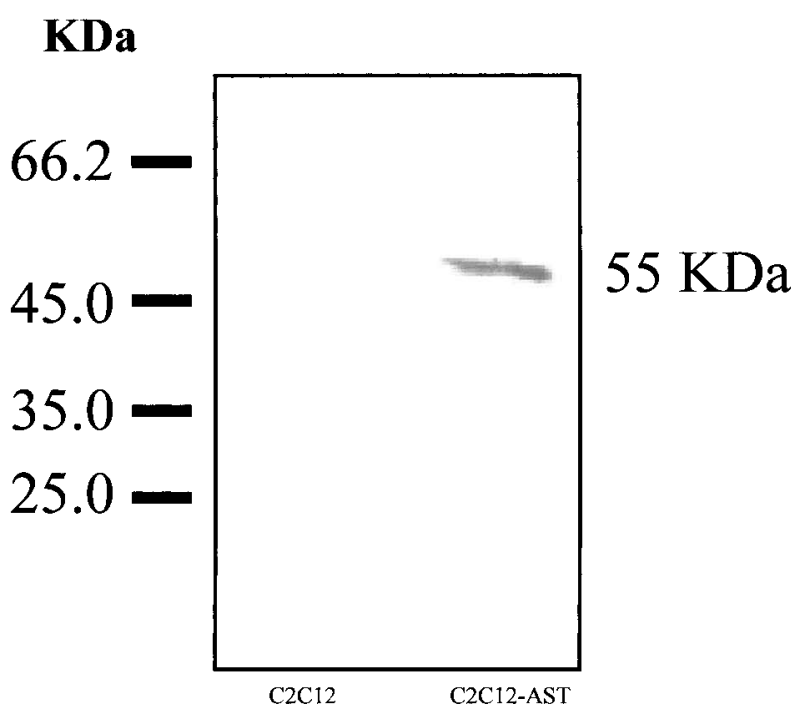

FIG. 1. Genetic engineering of a mouse myoblast $\mathrm{C} 2 \mathrm{C} 12$ cell line expressing angiostatin. $\mathrm{C} 2 \mathrm{C} 12$ cells were transfected with plasmid pRC-CMV-AST encoding angiostatin cDNA fused to a hemagglutinin (HA) tag. Media from individual clones were trichloroacetic acid precipitated and screened by Western blot analysis directed against the HA epitope. Forty-eight clones were screened and 40 were positive, as indicated by a $55-\mathrm{kDa}$ band corresponding to the angiostatin-HA fusion protein. 
Table 1. Encapsulated Cell Viability and Angiostatin Production ${ }^{\mathrm{a}}$

\begin{tabular}{lccccc}
\hline & \multicolumn{2}{c}{ In vitro incubation } & & \multicolumn{2}{c}{ In vivo incubation } \\
\cline { 2 - 3 } & Cells/capsule & $\begin{array}{c}\text { Angiostatin } \\
(\mathrm{pg} / \text { cell })\end{array}$ & & Cells/capsule & $\begin{array}{c}\text { Angiostatin } \\
(\mathrm{pg} / \text { cell })\end{array}$ \\
\hline Preimplant & $131 \pm 16$ & $3.78 \pm 0.26$ & & - & - \\
Day 7 & $166 \pm 9$ & $8.55 \pm 1.16$ & & $232 \pm 12$ & $6.82 \pm 2.35$ \\
Day 14 & $313 \pm 27$ & $6.08 \pm 0.82$ & & $501 \pm 51$ & $6.77 \pm 0.27$ \\
Day 21 & $352 \pm 38$ & $7.74 \pm 1.36$ & & $573 \pm 52$ & $6.09 \pm 0.47$ \\
\hline
\end{tabular}

${ }^{a}$ Microencapsulated C2C12-angiostatin cells were either kept under normal tissue culture conditions (in vitro incubation) or implanted intraperitoneally into C57BL/6 mice (in vivo incubation). At weekly intervals, microcapsules were withdrawn either from the culture dishes or from killed animals and incubated under normal tissue culture conditions for $24 \mathrm{hr}$. The microcapsules were analyzed for viable cell number and the media were analyzed for antiangiogenic activity. Data are an average from triplicate samples \pm standard error of the mean.

planted encapsulated cells showed less angiostatin expression ( $3.78 \mathrm{pg} / \mathrm{cell})$, as was normally observed immediately after the encapsulation process, but throughout the ensuing 3 weeks the expression level remained constant (6.08-8.55 pg/cell). Furthermore, there was no significant difference in the rate of angiostatin secretion between the in vitro and in vivo group over the 3-week period even though the encapsulated cells in the in vivo group showed higher levels of proliferation on all days examined. Therefore, angiostatin expression remained constant and stable over the intended prolonged period of implantation both in vitro and in vivo, whereas the in vivo environment was more conducive to sustained cell proliferation.

To confirm that this delivery system was sufficient to deliver angiostatin systemically, we implanted microencapsulated $\mathrm{C} 2 \mathrm{C} 12$-angiostatin cells intraperitoneally into normal C57BL/6 mice. Serum samples from these mice were then examined for antiangiogenic activity on cultured HUVECs (Fig. 2A). A consistent level of delivery from day 7 to day 21 at $\sim 5$ $\mu \mathrm{g}$ of angiostatin per milliliter of serum was obtained (Fig. 2A, normal control). As expected, the activities detected in serum samples from mock-treated normal animals (those receiving encapsulated $\mathrm{C} 2 \mathrm{C} 12$ cells) were not significantly different from background, that is, normal untreated mouse serum (Fig. 2A, mock control). Interestingly, when encapsulated angiostatin-expressing cells (C2C12-AST) were implanted into tumor-bearing mice, angiostatic activity in serum was not detected in the first 2 weeks after implantation but escalated rapidly in the following week (day 21) to $>10 \mu \mathrm{g}$ of angiostatin per milliliter of serum ((Fig. 2A, treated; $p \leq 0.01)$.

We hypothesized that the lack of systemic angiostatic activity in the first 2 weeks in treated mice bearing B16/neu tumors was in part due to sequestering of angiostatin to the tumors. We tested this hypothesis by again implanting encapsulated C2C12angiostatin cells into tumor-bearing mice as described above. Then, on day 14 after tumor induction, tumors and peritoneal organs in immediate contact with the implanted capsules were harvested and tissue extracts were assayed for antiangiogenic activity (Fig. 2B). It confirmed that in the presence of angiostatin-generating microcapsules, tumor tissue was highly enriched antiangiogenically $(\sim 80 \mathrm{ng}$ of angiostatin per microgram of protein), whereas none of the peritoneal organs showed any significant antiangiogenic activity. Western blot analysis against the HA tag confirmed that the recombinant HA-tagged angiostatin was indeed present within the tumors on day 14 after tumor induction at high levels and on day 21 at a lower level (Fig. 2C), consistent with the results from Fig. $2 \mathrm{~A}$.

The proof-of-principle experiment to show whether this treatment was an effective cancer therapy was to implant microencapsulated cells secreting angiostatin into tumor-bearing mice and monitor their tumor development and survival (Fig. 3). Early microcapsule implantation on day 3 after tumor induction was shown to suppress tumor growth more effectively than implantation on day 7 (Fig. 3A, day 3 treated versus day 7 treated), and both groups showed less tumor growth than the mock-treated group implanted on day 7 with encapsulated nontransfected cells (Fig. 3A, mock treated). There was no significant difference between the untreated control group and the mock treatment group. Day 3-treated tumors remained negligible in volume until approximately 18 days after tumor induction. In contrast, the day 7-treated group developed palpable tumors by day 11 , but at a rate about half of that of the untreated and mock-treated groups. These results were mirrored by the survival (Fig. 3B) of these groups of animals, showing that the efficacy of treatment was greater if the implantation was carried out earlier (day 3 versus day 7), whereas both treatment protocols showed efficacy when compared with mock-treated or untreated controls.

Several histological indices were quantified by examination of H\&E-stained tumor sections (Fig. 4A-C). These were morphometrically quantified and showed that tumor cell apoptosis (Fig. 4E) and areas of necrosis (Fig. 4F) increased significantly in treated animals (both at $p<0.001$ ) compared with animals in the mock-treated and untreated groups. In contrast, tumor mitosis remained unchanged irrespective of the treatment method (Fig. 4D).

The specific effect of the treatment on endothelial cells was investigated further by concurrent immunohistochemical staining for von Willebrand factor ( $\mathrm{vWF}$, an endothelial cell exclusive marker) and morphometric assessment of apoptosis (Fig. $5 \mathrm{D}$ and $\mathrm{E}$ ). It was shown that the encapsulation treatment resulted in a significant decrease in vWF-positive cells in the tumor (Fig. 5A and B versus Fig. 5C) and was confirmed with morphometric analysis of vWF-positive cells per unit area of tumor (Fig. 5D) ( $p<0.001$ compared with the untreated con- 
A)

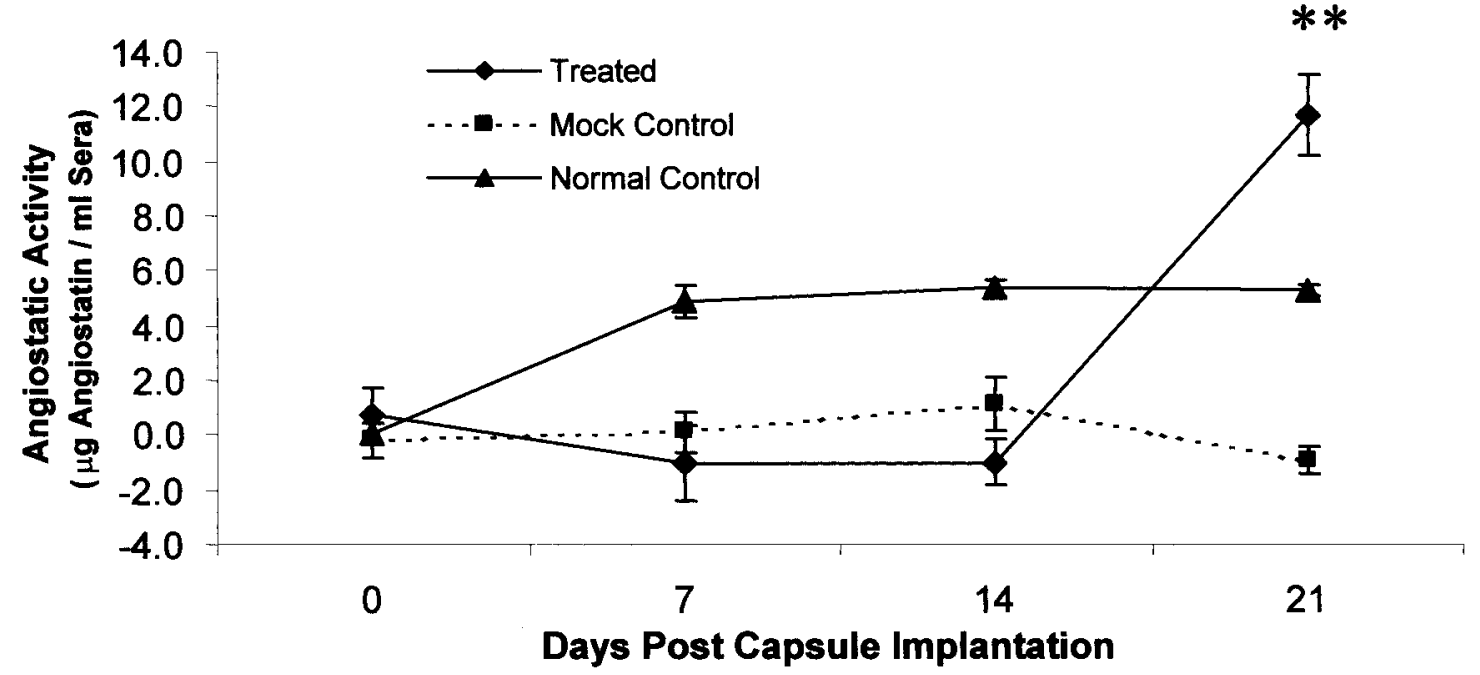

B)

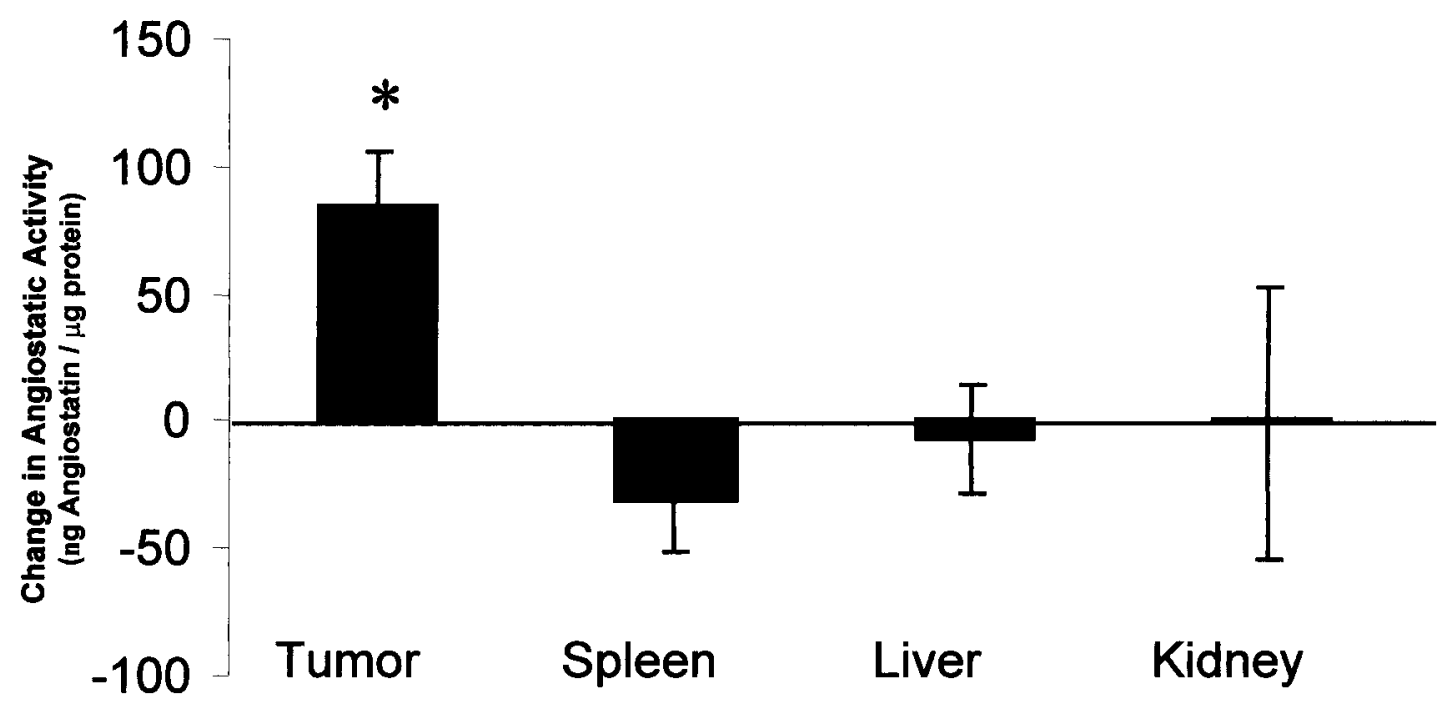

C)

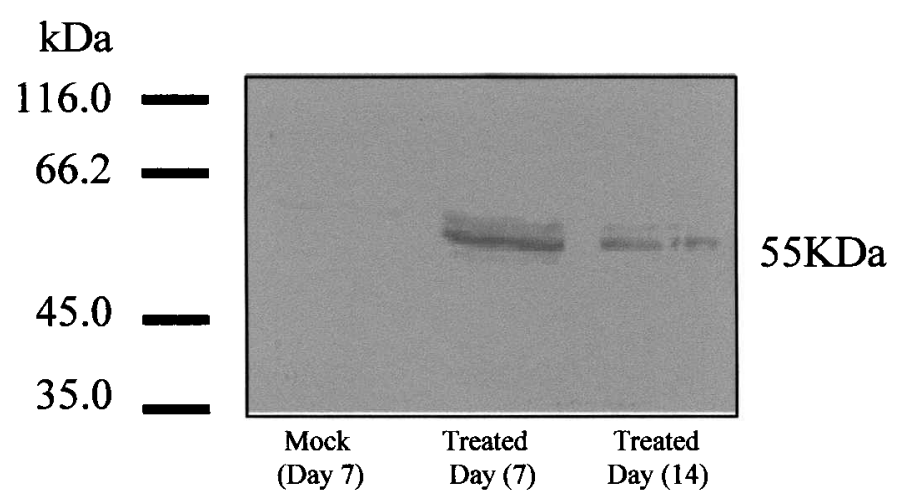

FIG. 2. Angiostatin delivery from microencapsulated cells. Mice were either injected with tumor cells or remained untreated. On day 3, $3 \mathrm{ml}$ of microcapsules was implanted intraperitoneally into each mouse. Each mouse belonged to one of the following three groups: normal mice implanted with encapsulated C2C12-angiostatin cells (normal control); tumor-bearing mice implanted with encapsulated C2C12 cells (mock control); tumor-bearing mice implanted with encapsulated C2C12-Angiostatin cells (treated). (A) Antiangiostatic activity was assayed in mouse serum on various days after tumor induction. All values were normalized to untreated normal mouse serum. (B) Angiostatin activity was assayed in tumors and peritoneal organs adjacent to the implantation site of treated tumor-bearing mice on day 14 after tumor induction. Mice had received microcapsule treatment on day 7 [as opposed to day 3 in (A)] to allow for tumors of sufficient volume to develop for analysis. Values were normalized to complementary tissue samples from untreated mice. (C) Western blot analysis against the HA tag of the fusion protein was performed on tissue extracts from tumors removed from treated mice 1-2 weeks after capsule implantation and (days 7 and 14 , respectively). The presence of an HA-tagged fusion protein was observed only in the treated tumor samples, with a more intense signal on day 14. $(* p<0.05 ; * * p<0.01$.) 
A)
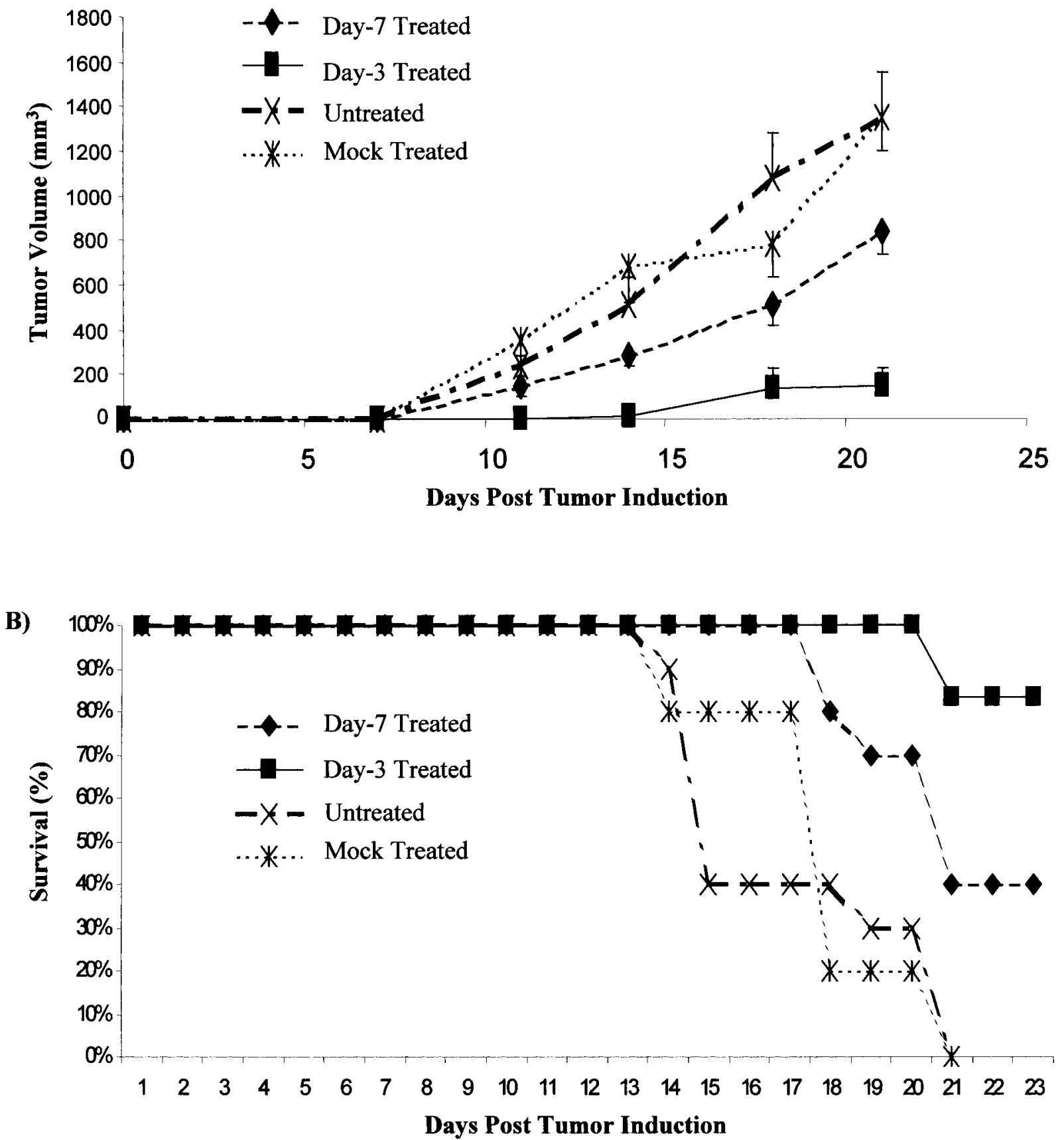

FIG. 3. Efficacy of treatment on B16/neu tumor-bearing mice. Four groups of mice (each $n=10$, except for the day 3-treated group with $n=6$ ) were injected with $\mathrm{B} 16 /$ neu tumor cells on day 0 . One group remained untreated as control (untreated), one group was treated with encapsulated but nontransfected $\mathrm{C} 2 \mathrm{C} 12$ cells (mock treated), one group was treated with $3 \mathrm{ml}$ of encapsulated C2C12-angiostatin cells on day 7 (day 7 treated), and one group was similarly treated on day 3 (day 3 treated). Tumor volume (A) and Kaplan-Meier survival (B) were monitored over time. Significant differences were obtained on day 21 between the mock and treated groups ( $p<0.05$ for the day 7-treated group; $p<0.01$ for the day 3-treated group).

trol). Furthermore, among the vWF-positive cells, there were those undergoing apoptosis (apoptotic index, $\sim 65 \%$ ) in treated tumors compared with that of the untreated control (5\%) (Fig. $5 \mathrm{E})$. Control sections stained in the absence of a primary antibody remained unstained, verifying the specificity of the immuno- staining for vWF. In addition, we were specific in designating a channel only in those structures showing a distinguishable erythrocyte-tumor interface. Hence, to the best of our judgment, and supported by our data, these vWF-deficient vessels are not artifacts. 

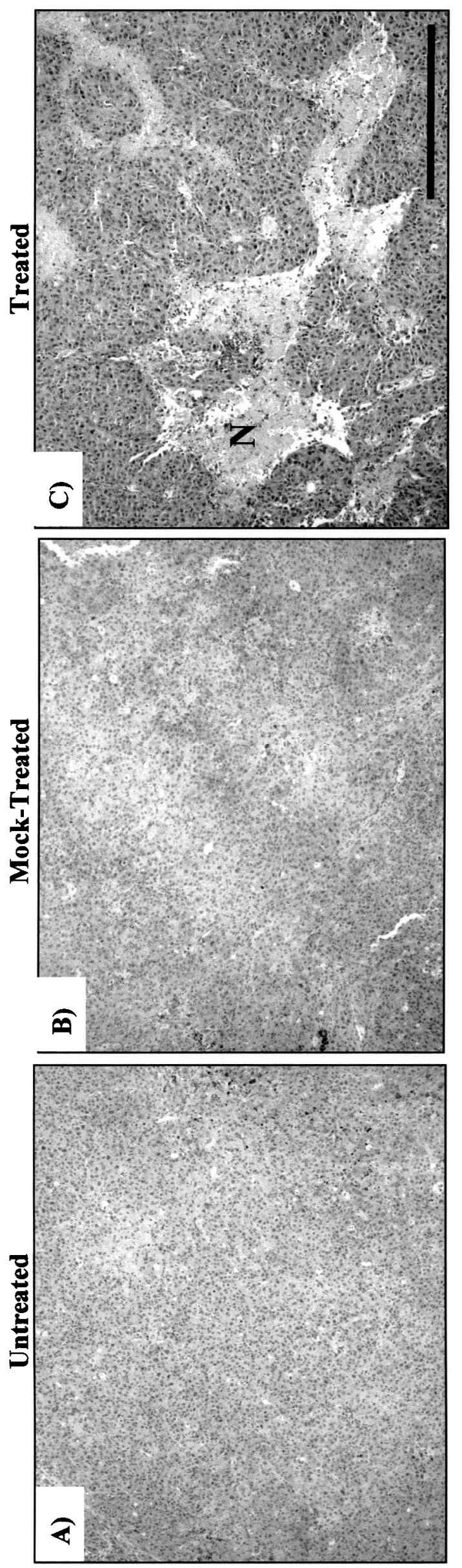

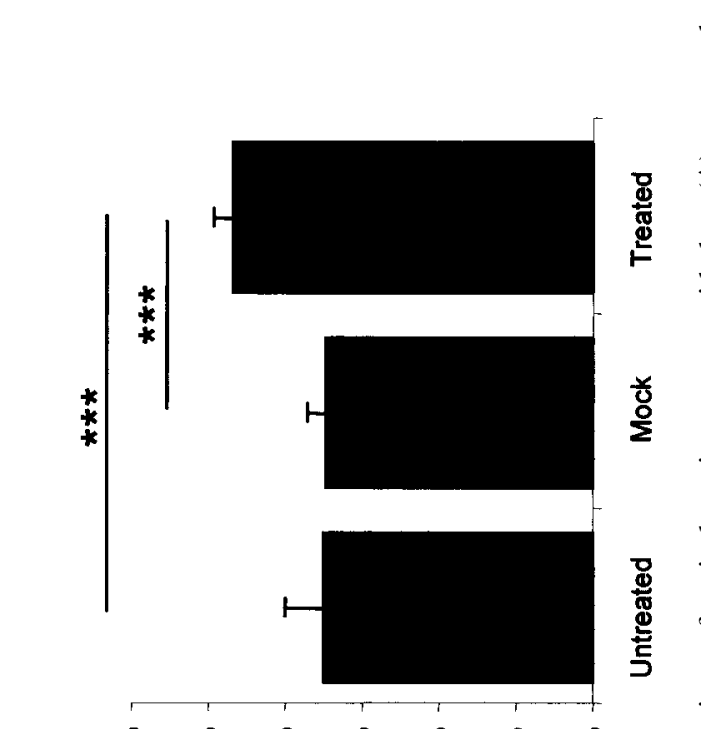

전

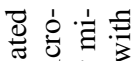

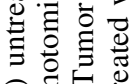

य记

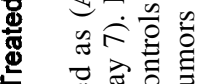

कृ

วิ $\Xi \cong$

므용

웡

告泀 。

过

可表

न ป

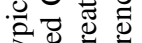

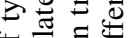

论

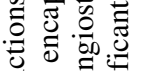

苍占

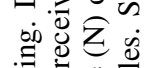

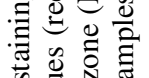

के

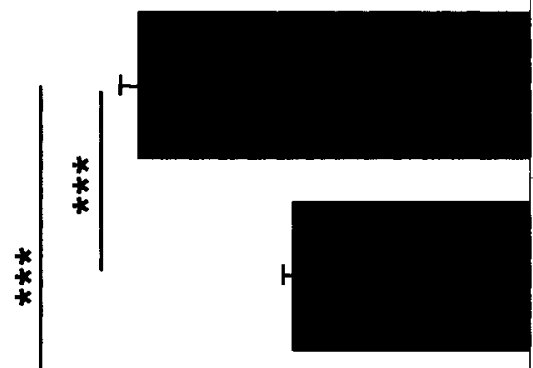

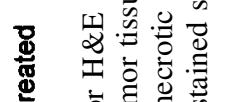

๘

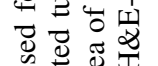

के

政

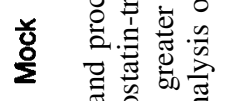

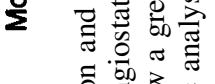

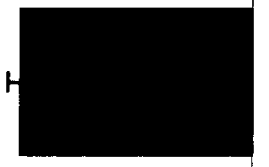

.0․ำ

\&

혀월

空言吕品

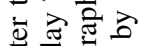

今े

A

政

オ0 을

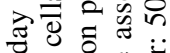

ธ느류

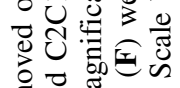

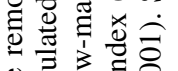

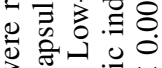

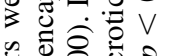

to 0 을

青文范

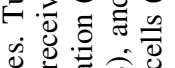

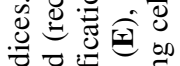

总素希

త⿹丁口

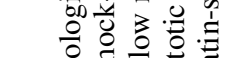

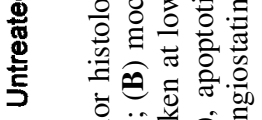

官苍完志

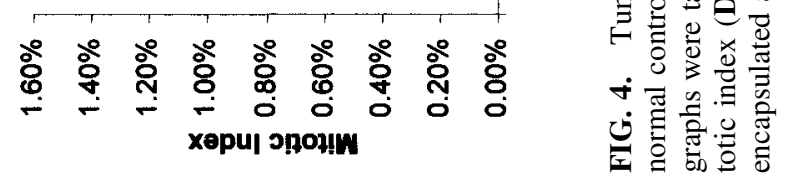




\section{Untreated}

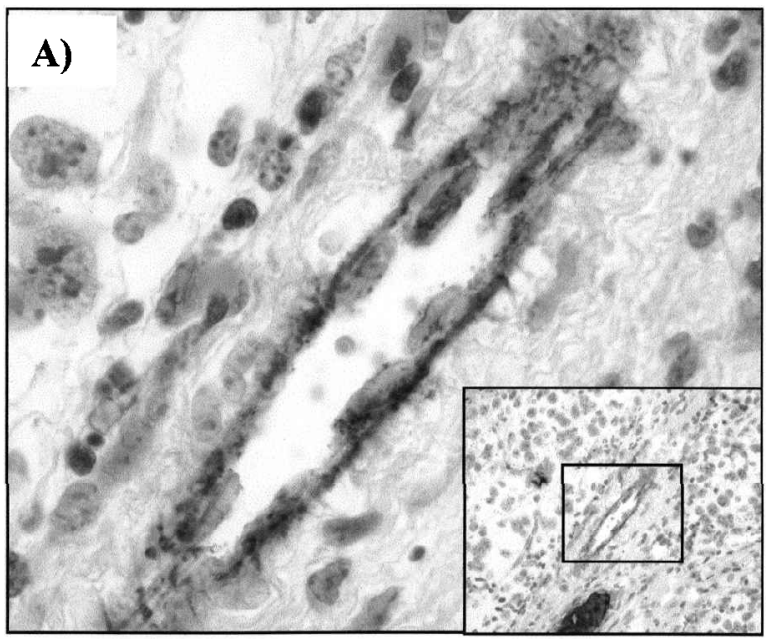

Mock-Treated

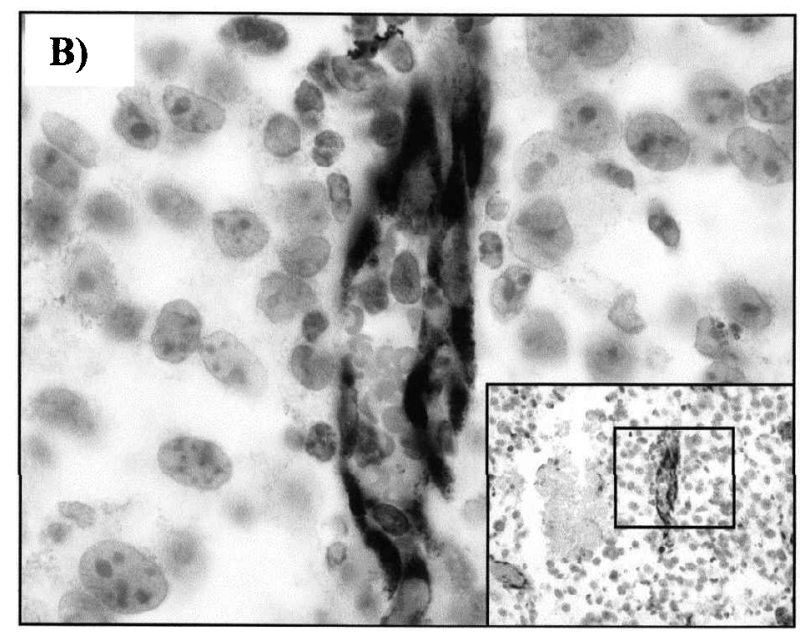

\section{Treated}

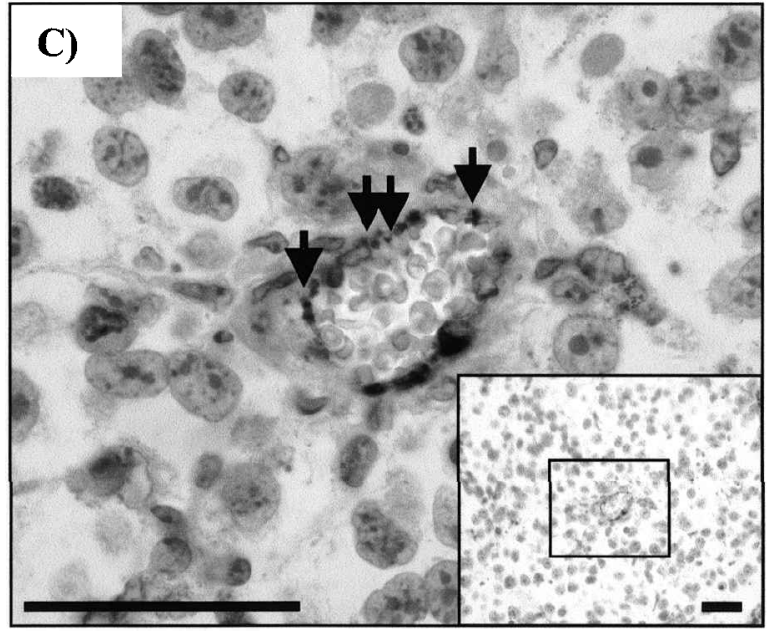

D)

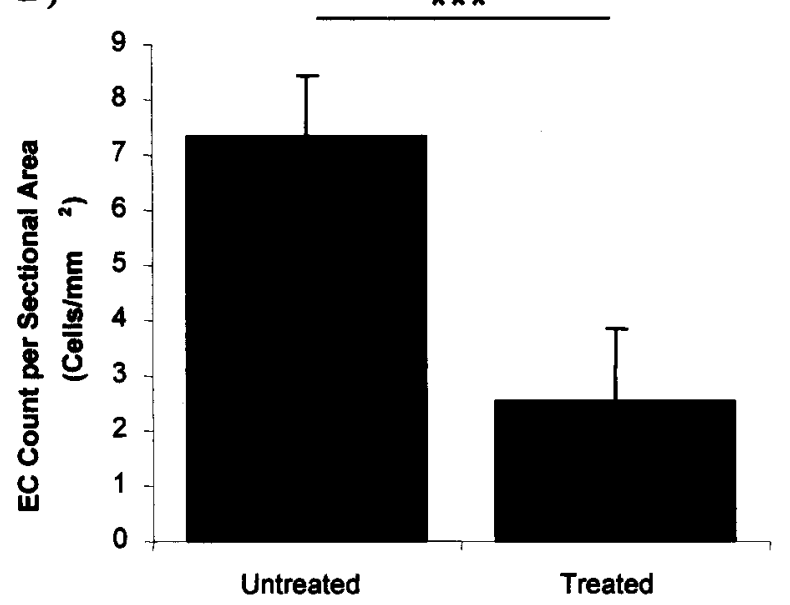

E)

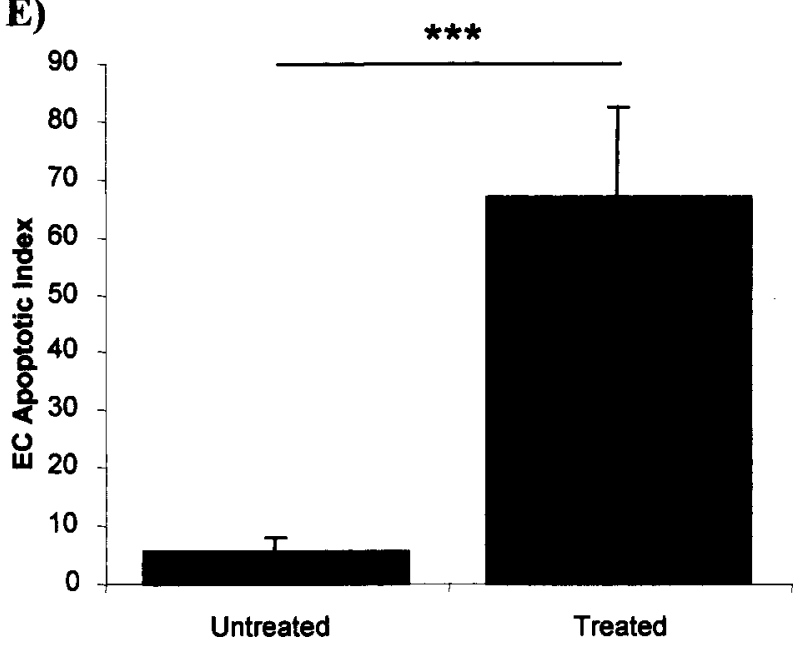

FIG. 5. Morphological assessment of apoptosis in vWF-positive cells. Tumors were removed for analysis on day 14 after tumor induction. Samples underwent immunohistochemical staining for von Willebrand factor in paraffin-embedded sections and were counterstained with hematoxylin. (A) Untreated control; (B) mock treated (receiving encapsulated C2C12 cells on day 7); (C) angiostatin treated (receiving encapsulated C2C12-AST cells on day 7). Photomicrographs of stained tissues were taken at high magnification $(\times 1000)$ and medium magnification (insets; $\times 400)$. Cells were assessed to be vWF positive on the basis of intensity of staining and quality of the nuclei in positively stained cells. Some positively stained cells (predominantly in angiostatin-treated tumors) appeared to have undergone condensation consistent with apoptosis (solid arrows; C). (D) vWF-positive endothelial cell (EC) number per sectional area of tumor. (E) Apoptotic index of tumoral endothelial cells as determined by morphometric analysis [as depicted in (C)]. Significant differences were observed in tumors treated with encapsulated angiostatin-secreting cells $(* * * p<0.001)$. Scale bars: $5 \mu \mathrm{m}$. 
Although it was clear that the endothelial cell content of angiostatin-treated tumors was drastically reduced, tumors were eventually able to grow after the initial weeks or treatment (Fig. 3A) despite their apparent loss of vasculature. To assess what may be occurring in these tumors, we examined paraffin-embedded sections of 21-day tumor samples after a 2-week treatment with microencapsulated $\mathrm{C} 2 \mathrm{C} 12$-angiostatin cells (or with microencapsulated $\mathrm{C} 2 \mathrm{C} 12$ cells as a sham control) by im-
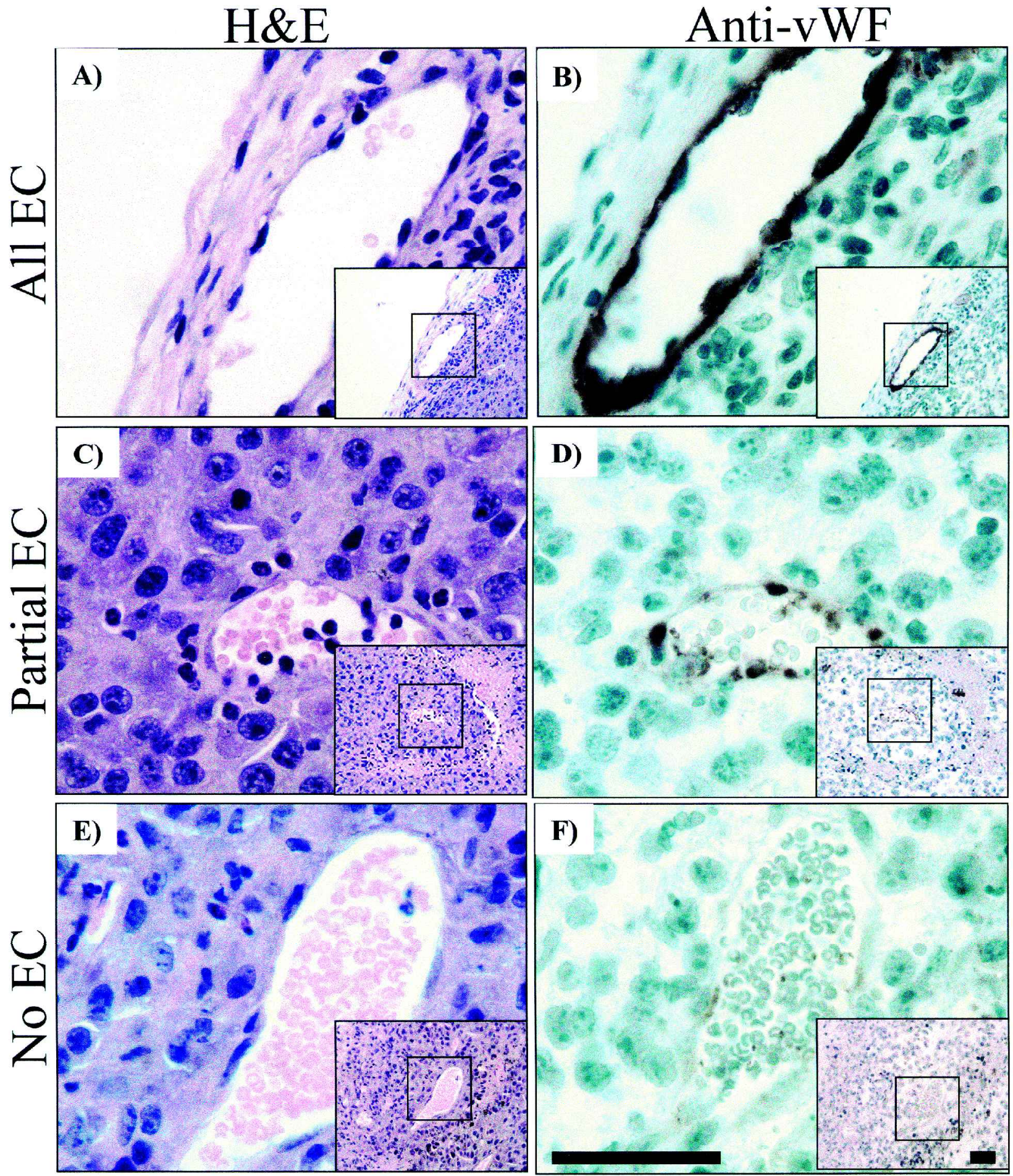

FIG. 6. Vascular channels lack vWF-positive endothelial cells in treated tumors. Anti-vWF-stained tumor vasculature (day 21 after tumor induction; received encapsulated C2C12-AST cells on day 7) was assessed for endothelial cell content. Two-micron serial sections were stained with $\mathrm{H} \& \mathrm{E}(\mathbf{A}, \mathbf{C}$, and $\mathbf{E})$ and compared with adjacent sections stained for vWF (hematoxylin counterstained) (B, D, and $\mathbf{F}$ ). Various types of tumor vasculature were observed to consist of vessel walls with a continuous perimeter of endothelial cells (A and B), or with discontinuous staining for endothelial cells ( $\mathbf{C}$ and $\mathbf{D}$ ), or with an absence of endothelial cells at the tumor-erythrocyte interface ( $\mathbf{E}$ and $\mathbf{F})$. Scale bars: $5 \mu \mathrm{m}$. 
munohistochemical staining for vWF to identify tumor-associated endothelial cells (Fig. 6). There were normal blood vessels lined with vWF-positive endothelialcells within the tumors (Fig. 6A and B). However, we also found extravasated erythrocytes within tumors that lacked an intact lining of vWFpositive endothelial cells (Fig. 6C and D) or were even completely denuded of any endothelial lining (Fig. 6E and F). These areas of endothelial loss occurred predominantly in tumors from mice that received antiangiogenic therapy. This was confirmed by computer-aided morphometric analysis to blindly assess tumor vasculature according to endothelial cell content, that is, vasculature samples were grouped according to whether they included a continuous lining of endothelial cells (Fig. 7, all EC), a partially lined vessel (Fig. 7, partial EC), or erythrocyte islands with no discernible endothelial cells (Fig. 7, no EC). It was clear that in the angiostatin-treated group, the proportion of vasculature without endothelial cell lining was significantly higher than that of the mock-treated animals. This increase was associated with a loss of vasculature with intact endothelial cell lining, and was accompanied by an increase in the proportion of vasculature that was incompletely lined with endothelial cells.

\section{DISCUSSION}

Antiangiogenic therapy of cancer by a similar immunoisolated nonautologouscell approach has been reported previously by two independent groups (Joki et al., 2001; Read et al., 2001). Both groups had treated glioma models of cancer with xenogeneically derived cell lines genetically modified to secrete endostatin, a known angiogenic inhibitor (O'Reilly et al., 1997). In this study, we chose an allogeneic cell line to transplant $(\mathrm{C} 3 \mathrm{H}$ mouse-derived $\mathrm{C} 2 \mathrm{C} 12$ cells implanted into $\mathrm{C} 57 \mathrm{BL} / 6$ mice) as this better represents what we envision for future clinical application. Despite the differences in model systems, the aspects of antiangiogenic therapy delivered in this method are consistent. Joki et al. (2001) had shown a delay in tumor growth similar to that in this report (Fig. 3A) as well as decreased vascu- lar density and an increased apoptotic rate with no change in tumor proliferation, as noted here in Fig. 4. Increased tumor necrosis and improved survival were also noted in our study (Fig. 3B), consistent with what was seen by Read et al. (2001).

In the presence of tumor, no angiostatin was detected systemically in treated mice during the first 2 weeks despite obvious early efficacy (Fig. 2A). However, tumor extracts from these mice were enriched in angiostatic activity compared with untreated controls (Fig. 2B), associated with the presence of recombinant HA-tagged angiostatin in the tumor (Fig. 2C). The angiostatic activity observed in these mice was consistent with what is secreted from the microcapsules as derived from the data in Table 1, taking into account the possible 2.0- to 2.5-day half-life of angiostatin (Hatton et al., 2001). It appears that a significant portion of the angiostatin delivered becomes localized at the tumor. It is currently unknown why angiostatin seems to localize to tumors, although potential receptors for angiostatin exist on proliferating endothelial cells (Moser et al., 1999), which should be prevalent in tumors. Potential receptors reported for angiostatin include an ATP synthase on the surface of human endothelial cells (Moser et al., 1999) as well as $\alpha_{\mathrm{v}} \beta_{3}$-integrin (Tarui et al., 2001, 2002) and vitronectin (Mulligan-Kehoe et al., 2001). This may account for the angiostatin localization to the tumor instead of to other internal organs near the capsule implantation site (Fig. 2B). When considering the amount of angiostatin in the whole tumor relative to the amount delivered to the mouse on a given day, there was approximately 1000-fold more antiangiogenic activity within treated tumors than expected (determined by extrapolating back from angiostatin per unit mass of protein to wet weight of tumor and tumor volume). Previous studies have shown that angiostatin could inhibit vascular endothelial growth factor (VEGF) and basic fibroblast growth factor (bFGF) mRNA generation in primary glioma tumors (Kirsch et al., 1998). This may explain the high level of antiangiogenic activity in the angiostatin-treated tumors. The reduced tumor endothelial cell counts (and thereby the reduction in most tumor-exclusive receptors for angiostatin) may also explain the prevalence of angiostatin observed sys-

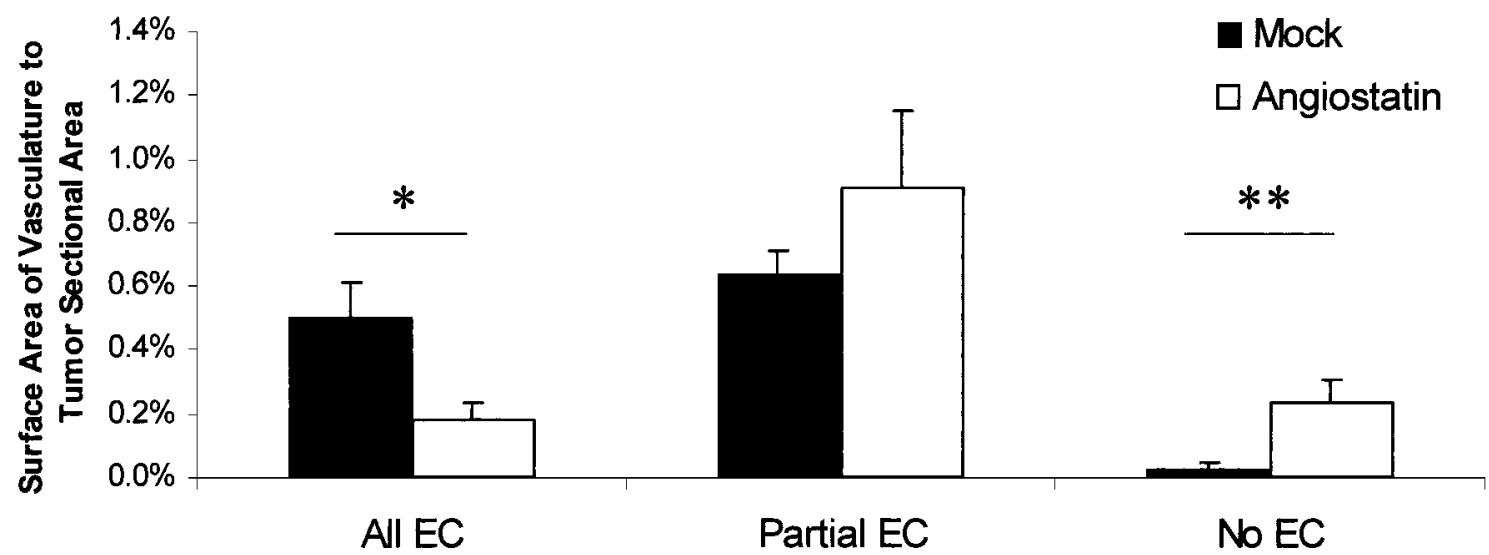

FIG. 7. Grouping of tumor vasculature according to endothelial cell content. Tumors harvested from mock-treated or treated mice were processed as described for Fig. 6. Tumor vasculature was assessed in a blinded manner and quantified into units of vascular area per tumor sectional area. Vascular structures were thereafter grouped according to criteria defined in Fig. 6. Values represent data from entire tumor sections (five per group) from triplicate mice per group. Statistical significance of angiostatin-treated samples relative to mock-treated samples: $* p<0.05 ; * * p<0.01$. 
temically later in the treatment. In addition, because the angiostatin detected in the tumors still retained a molecular mass of $55 \mathrm{kDa}$ (Fig. 2C), no posttranslational proteolytic hydrolysis had occurred and the recombinant product was associated with antiangiogenic activity. The late detection of angiostatin in serum samples may indicate that the supply of potential receptors for angiostatin was being eliminated as tumor endothelial cells were eliminated. However, it is generally accepted that tumors require some form of vasculature to grow. Although endothelial cell counts per sectional tumor area showed a significant decrease on treatment with angiostatin, it was clear that the tumors were still able to progress eventually (Fig. 3A). This indicates some method by which tumors escape growth inhibition by angiostatin treatment despite elimination of a majority of the endothelial cell content of these tumors. The increased prevalence of vascular channels devoid of endothelial cells on antiangiogenic treatment supports the hypothesis that there exists a mechanism by which tumors are able to sustain such a channel and thereby escape antiangiogenic therapy.

It is likely that some form of vascular mimicry is involved in maintaining the cancer. The term "vasculogenic mimicry" has been used to describe the generation of microvascular channels by genetically deregulated, aggressive tumor cells. This emphasizes their de novo generation without the participation of endothelial cells and independent of angiogenesis (Maniotis et al., 1999; Kobayashi et al., 2002; Shirakawa et al., 2002). Tumor vascularization in the absence of endothelial cells (Pezzella et al., 1997; Maniotis et al., 1999) has been shown in these B16 tumors and has been previously observed in highly invasive and metastatic melanomas (Maniotis et al., 1999). This would account for the lack of complete efficacy observed in the treatment of the B16/neu tumor model in the day 7-treated group (Fig. 3) despite favorable histological indices (Figs. 4 and 5) that would otherwise indicate sustained inhibition of melanoma growth.

From this work, several conclusions may be drawn. First, encapsulated myoblasts maintain a constant level of expression with respect to the CMV-driven angiostatin gene, and this low dose of angiostatin is sufficient to suppress tumor progression (Fig. 3). Indeed, tumor tissues from such treatment show a net loss of angiogenic activity compared with untreated tumors, concurrent with a substantial decrease in tumor volume (Fig. 2A), increased apoptosis (Fig. 4E), and increased necrosis (Fig. $4 F)$. Second, antiangiogenic-based therapy is not sufficient to eliminate tumors in the long term, especially if treatment is initiated late in the course of tumor progression(Fig. 2A). Tumors have been shown to be able to sustain their own vascular bed despite substantial loss of endothelial cells (Figs. 6 and 7). Hence, the vascular mimicry that may occur in some tumor types will require careful molecular typing of tumors to ensure the exclusion of such tumors for treatment.

In summary, the use of microencapsulated cells to deliver angiostatin offers the potential to overcome some of the obstacles to the use of antiangiogenic protein therapy as outlined in a review (Cao, 2000). Examples include the potentially lifelong, prolonged therapy, the repeated high-dose (grams per day) administrations, as well as the cost and risks of toxicity associated with such high doses. Hence, antiangiogenesis gene or cell-based therapy can target the growing population of genetically stable endothelial cells directly, and thereby inhibit tu- mor growth independently of tumor cell heterogeneity and tumor cell type (Kerbel, 1997).

\section{ACKNOWLEDGMENTS}

We thank Stephanie Leah Gora for helping with much of the morphometric analysis, Dr. Mark W. Hatton for providing purified rabbit angiostatin, and the Canadian Breast Cancer Research Initiative and the Canadian Institutes of Health Research for grant support. For this work, Pasquale Cirone has been the recipient of the McMaster University Graduate Student Scholarship (1999-2001 and 2001-2002) as well as the Lee Nielson Roth Award for Medical Science (Cancer).

\section{REFERENCES}

AL-HENDY, A., HORTELANO, G., TANNENBAUM, G.S., and CHANG, P.L. (1995). Correction of the growth defect in dwarf mice with nonautologous microencapsulated myoblasts: An alternate approach to somatic gene therapy. Hum. Gene Ther. 6, 165-175.

BARENDSZ-JANSON, A.F., GRIFFIOEN, A.W., MULLER, A.D., DAM-MIERAS, M.C., and HILLEN, H.F. (1998). In vitro tumor angiogenesis assays: Plasminogen lysine binding site 1 inhibits in vitro tumor-induced angiogenesis. J. Vasc. Res. 35, 109-114.

CAO, Y. (2000). Antiangiogenic gene therapy. Gene Ther. Regul. 1, $123-139$.

CAO, Y., JI, R.W., DAVIDSON, D., SCHALLER, J., MARTI, D., SOHNDEL, S., MCCANCE, S.G., O'REILLY, M.S., LLINAS, M., and FOLKMAN, J. (1996). Kringle domains of human angiostatin: Characterization of the anti-proliferative activity on endothelial cells. J. Biol. Chem. 271, 29461-29467.

CAO, Y., O'REILLY, M.S., MARSHALL, B., FLYNN, E., JI, R.W., and FOLKMAN, J. (1998). Expression of angiostatin cDNA in a murine fibrosarcoma suppresses primary tumor growth and produces long-term dormancy of metastases. J. Clin. Invest. 101, 1055-1063.

CHANG, P.L. (1995). Nonautologous somatic gene therapy. In Somatic Gene Therapy. P.L. Chang, ed. (CRC Press, Boca Raton, FL) pp. 203-223.

CHANG, P.L., VAN RAAMSDONK, J.M., HORTELANO, G., BARSOUM, S.C., MACDONALD, N.C., and STOCKLEY, T.L. (1999). The in vivo delivery of heterologous proteins by microencapsulated recombinant cells. Trends Biotechnol. 17, 78-83.

CIRONE, P., SALLER, R.M., and CHANG, P.L. (2001). Immuno-isolation in oncology: A mini-review. Curr. Pharm. Biotechnol. 2, 269-277.

CIRONE, P., BOURGEOIS, J.M., AUSTIN, R.C., and CHANG, P.L. (2002). A novel approach to tumor suppression with microencapsulated recombinant cells. Hum. Gene Ther. 13, 1157-1166.

CLAESSON-WELSH, L., WELSH, M., ITO, N., ANAND-APTE, B., SOKER, S., ZETTER, B., O'REILLY, M., and FOLKMAN, J. (1998). Angiostatin induces endothelial cell apoptosis and activation of focal adhesion kinase independently of the integrin-binding motif RGD. Proc. Natl. Acad. Sci. U.S.A. 95, 5579-5583.

GATELY, S., TWARDOWSKI, P., STACK, M.S., PATRICK, M., BOGGIO, L., CUNDIFF, D.L., SCHNAPER, H. W., MADISON, L., VOLPERT, O., BOUCK, N., ENGHILD, J., KWAAN, H.C., and SOFF, G.A. (1996). Human prostate carcinoma cells express enzymatic activity that converts human plasminogen to the angiogenesis inhibitor, angiostatin. Cancer Res. 56, 4887-4890.

GATELY, S., TWARDOWSKI, P., STACK, M.S., CUNDIFF, D.L., GRELLA, D., CASTELLINO, F.J., ENGHILD, J., KWAAN, H.C., LEE, F., KRAMER, R.A., VOLPERT, O., BOUCK, N., and SOFF, 
G.A. (1997). The mechanism of cancer-mediated conversion of plasminogen to the angiogenesis inhibitor angiostatin. Proc. Natl. Acad. Sci. U.S.A. 94, 10868-10872.

GRISCELLI, F., LI, H., BENNACEUR-GRISCELLI, A., SORIA, J., OPOLON, P., SORIA, C., PERRICAUDET, M., YEH, P., and LU, H. (1998). Angiostatin gene transfer: Inhibition of tumor growth in vivo by blockage of endothelial cell proliferation associated with a mitosis arrest. Proc. Natl. Acad. Sci. U.S.A. 95, 6367-6372.

GRISCELLI, F., LI, H., CHEONG, C., OPOLON, P., BENNACEURGRISCELLI, A., VASSAL, G., SORIA, J., SORIA, C., LU, H., PERRICAUDET, M., and YEH, P. (2000). Combined effects of radiotherapy and angiostatin gene therapy in glioma tumor model. Proc. Natl. Acad. Sci. U.S.A. 97, 6698-6703.

HATTON, M.W., DAY, S., SOUTHWARD, S.M., DERESKE, M., ROSS, B., SEIDLITZ, E., SINGH, G., and RICHARDSON, M. (2001). Metabolism of rabbit angiostatin glycoforms I and II in rabbits: Angiostatin-I leaves the intravascular space faster and appears to have greater anti-angiogenic activity than angiostatin-II. J. Lab Clin. Med. 138, 83-93.

HEIDTMANN, H.H., NETTELBECK, D.M., MINGELS, A., JAGER, R., WELKER, H.G., and KONTERMANN, R.E. (1999). Generation of angiostatin-like fragments from plasminogen by prostate-specific antigen. Br. J. Cancer 81, 1269-1273.

HEIKE, Y., TAKAHASHI, M., OHIRA, T., NARUSE, I., HAMA, S., OHE, Y., KASAI, T., FUKUMOTO, H., OLSEN, K.J., PODACK, E.E., and SAIJO, N. (1997). Genetic immunotherapy by intrapleural, intraperitoneal and subcutaneous injection of IL-2 gene-modified Lewis lung carcinoma cells. Int. J. Cancer 73, 844-849.

JOKI, T., MACHLUF, M., ATALA, A., ZHU, J., SEYFRIED, N.T., DUNN, I.F., ABE, T., CARROLL, R.S., and BLACK, P.M. (2001). Continuous release of endostatin from microencapsulated engineered cells for tumor therapy. Nat. Biotechnol. 19, 35-39.

KERBEL, R.S. (1997). A cancer therapy resistant to resistance. Nature 390, 335-336.

KIRSCH, M., STRASSER, J., ALLENDE, R., BELLO, L., ZHANG, J., and BLACK, P.M. (1998). Angiostatin suppresses malignant glioma growth in vivo. Cancer Res. 58, 4654-4659.

KOBAYASHI, H., SHIRAKAWA, K., KAWAMOTO, S., SAGA, T., SATO, N., HIRAGA, A., WATANABE, I., HEIKE, Y., TOGASHI, K., KONISHI, J., BRECHBIEL, M.W., and WAKASUGI, H. (2002). Rapid accumulation and internalization of radiolabeled herceptin in an inflammatory breast cancer xenograft with vasculogenic mimicry predicted by the contrast-enhanced dynamic MRI with the macromolecular contrast agent G6-(1B4M-Gd) 256 . Cancer Res. 62, 860-866.

KROGER, J.C., BERGMEISTER, H., HOFFMEYER, A., CEIJNA, M., KARLE, P., SALLER, R., SCHWENDENWEIN, I., VON ROMBS, K., LIEBE, S., GUNZBURG, W.H., SALMONS, B., HAUENSTEIN, K., LOSERT, U., and LOHR, M. (1999). Intraarterial instillation of microencapsulated cells in the pancreatic arteries in pig. Ann. N.Y. Acad. Sci. 880, 374-378.

LANNUTTI, B.J., GATELY, S.T., QUEVEDO, M.E., SOFF, G.A., and PALLER, A.S. (1997). Human angiostatin inhibits murine hemangioendothelioma tumor growth in vivo. Cancer Res. 57, 5277-5280.

LUCAS, R., HOLMGREN, L., GARCIA, I., JIMENEZ, B., MANDRIOTA, S.J., BORLAT, F., SIM, B.K., WU, Z., GRAU, G.E., SHING, Y., SOFF, G.A., BOUCK, N., and PEPPER, M.S. (1998). Multiple forms of angiostatin induce apoptosis in endothelial cells. Blood 92, 4730-4741.

MACDONALD, N.J., MURAD, A.C., FOGLER, W.E., LU, Y., and SIM, B.K. (1999). The tumor-suppressing activity of angiostatin protein resides within kringles 1 to 3 . Biochem. Biophys. Res. Commun. 264, 469-477.

MANIOTIS, A.J., FOLBERG, R., HESS, A., SEFTOR, E.A., GARDNER, L.M., PE'ER, J., TRENT, J.M., MELTZER, P.S., and HENDRIX, M.J. (1999). Vascular channel formation by human melanoma cells in vivo and in vitro: Vasculogenic mimicry. Am. J. Pathol. 155, 739-752.

MORIKAWA, W., YAMAMOTO, K., ISHIKAWA, S., TAKEMOTO, S., ONO, M., FUKUSHI, J., NAITO, S., NOZAKI, C., IWANAGA, S., and KUWANO, M. (2000). Angiostatin generation by cathepsin D secreted by human prostate carcinoma cells. J. Biol. Chem. 275, 38912-38920.

MOSER, T.L., STACK, M.S., ASPLIN, I., ENGHILD, J.J., HOJRUP, P., EVERITT, L., HUBCHAK, S., SCHNAPER, H.W., and PIZZO, S.V. (1999). Angiostatin binds ATP synthase on the surface of human endothelial cells. Proc. Natl. Acad. Sci. U.S.A. 96, 2811-2816. MULLIGAN-KEHOE, M.J., WAGNER, R., WIELAND, C., and POWELL, R. (2001). A truncated plasminogen activator inhibitor-1 protein induces and inhibits angiostatin (kringles 1-3), a plasminogen cleavage product. J. Biol. Chem. 276, 8588-8596.

O'REILLY, M.S., HOLMGREN, L., SHING, Y., CHEN, C., ROSENTHAL, R.A., MOSES, M., LANE, W.S., CAO, Y., SAGE, E.H., and FOLKMAN, J. (1994). Angiostatin: A novel angiogenesis inhibitor that mediates the suppression of metastases by a Lewis lung carcinoma. Cell 79, 315-328.

O'REILly, M.S., HOLMGREN, L., CHEN, C., and FOLKMAN, J. (1996). Angiostatin induces and sustains dormancy of human primary tumors in mice. Nat. Med. 2, 689-692.

O'REILLY, M.S., BOEHM, T., SHING, Y., FUKAI, N., VASIOS, G., LANE, W.S., FLYNN, E., BIRKHEAD, J.R., OLSEN, B.R., and FOLKMAN, J. (1997). Endostatin: An endogenous inhibitor of angiogenesis and tumor growth. Cell 88, 277-285.

PEIRONE, M.A., ROSS, C.J.D., HORTELANO, G., BRASH, J.L., and CHANG, P.L. (1998). Encapsulation of various recombinant mammalian cell types in different alginate microcapsules. J. Biomed. Mater. Res. 42, 587-596.

PEZZELla, F., PASTORINO, U., TAGLIABUE, E., ANDREOLA, S., SOZZI, G., GASPARINI, G., MENARD, S., GATTER, K.C., HARRIS, A.L., FOX, S., BUYSE, M., PILOTTI, S., PIEROTTI, M., and RILKE, F. (1997). Non-small-cell lung carcinoma tumor growth without morphological evidence of neo-angiogenesis. Am. J. Pathol. 151, 1417-1423.

PRAKASH, S., and CHANG, T.M. (1996). Microencapsulated genetically engineered live $E$. coli $\mathrm{DH} 5$ cells administered orally to maintain normal plasma urea level in uremic rats. Nat. Med. 2, 883-887.

READ, T.A., SORENSEN, D.R., MAHESPARAN, R., ENGER, P.O., TIMPL, R., OLSEN, B.R., HJELSTUEN, M.H., HARALDSETH, O., and BJERKVIG, R. (2001). Local endostatin treatment of gliomas administered by microencapsulated producer cells. Nat. Biotechnol. 19, 29-34

RINSCH, C., REGULIER, E., DEGLON, N., DALLE, B., BEUZARD, Y., and AEBISCHER, P. (1997). A gene therapy approach to regulated delivery of erythropoietin as a function of oxygen tension. Hum. Gene Ther. 8, 1881-1889.

ROSS, C.J.D., BASTEDO, L., MAIER, S.A., SANDS, M.S., and CHANG, P.L. (2000a). Treatment of a lysosomal storage disease, mucopolysaccharidosis VII, with microencapsulated recombinant cells. Hum. Gene Ther. 11, 2117-2127.

ROSS, C.J.D., RALPH, M.R., and CHANG, P.L. (2000b). Somatic gene therapy of a neurodegenerative lysosomal storage disease using microencapsulated recombinant cells. (Submitted.)

SACCO, M.G., CANIATTI, M., CATO, E.M., FRATTINI, A., CHIESA, G., CERUTI, R., ADORNI, F., ZECCA, L., SCANZIANI, E., and VEZZONI, P. (2000). Liposome-delivered angiostatin strongly inhibits tumor growth and metastatization in a transgenic model of spontaneous breast cancer. Cancer Res. 60, 2660-2665.

SAMBROOK, J., MANIATIS, T., and FRITSCH, E.F. (1989). Molecular Cloning: A Laboratory Manual, 2nd Ed. (Cold Spring Harbor Laboratory Press, Cold Spring Harbor, NY).

SHIRAKAWA, K., KOBAYASHI, H., HEIKE, Y., KAWAMOTO, S., BRECHBIEL, M.W., KASUMI, F., IWANAGA, T., KONISHI, F., 
TERADA, M., and WAKASUGI, H. (2002). Hemodynamics in vasculogenic mimicry and angiogenesis of inflammatory breast cancer xenograft. Cancer Res. 62, 560-566.

SIM, B.K., O'REILLY, M.S., LIANG, H., FORTIER, A.H., HE, W., MADSEN, J.W., LAPCEVICH, R., and NACY, C.A. (1997). A recombinant human angiostatin protein inhibits experimental primary and metastatic cancer. Cancer Res. 57, 1329-1334.

STACK, M.S., GATELY, S., BAFETTI, L.M., ENGHILD, J.J., and SOFF, G.A. (1999). Angiostatin inhibits endothelial and melanoma cellular invasion by blocking matrix-enhanced plasminogen activation. Biochem. J. 340, 77-84.

TARUI, T., MILES, L.A., and TAKADA, Y. (2001). Specific interaction of angiostatin with integrin $\alpha_{\mathrm{v}} \beta_{3}$ in endothelial cells. J. Biol. Chem. 276, 39562-39568.

TARUI, T., MAJUMDAR, M., MILES, L.A., RUF, W., and TAKADA, Y. (2002). Plasmin-induced migration of endothelial cells: A potential target for the anti-angiogenic action of angiostatin. J. Biol. Chem. 277, 33564-33570.

VAN RAAMSDONK, J.M., and CHANG, P.L. (2001). Osmotic pressure test: A simple, quantitative method to assess the mechanical stability of alginate microcapsules. J. Biomed. Mater. Res. 54, 264-271.

VAN RAAMSDONK, J.M., ROSS, C.J., POTTER, M.A., KURACHI, S., KURACHI, K., STAFFORD, D.W., and CHANG, P.L. (2002).
Treatment of hemophilia B in mice with nonautologous somatic gene therapeutics. J. Lab. Clin. Med. 139, 35-42.

WU, Z., O'REILLY, M.S., FOLKMAN, J., and SHING, Y. (1997). Suppression of tumor growth with recombinant murine angiostatin. Biochem. Biophys. Res. Commun. 236, 651-654.

Address reprint requests to: Dr. Patricia L. Chang Department of Pediatrics Health Sciences Centre, Room 3N18

McMaster University 1200 Main Street West Hamilton, ON L8N 3Z5, Canada

E-mail: changp@mcmaster.CA

Received for publication January 7, 2003; accepted after revision May 13, 2003.

Published online: June 5, 2003. 